\title{
LIM Domain-Containing Protein 1
}

National Cancer Institute

\section{Source}

National Cancer Institute. LIM Domain-Containing Protein 1. NCI Thesaurus. Code C29919.

LIM domain-containing protein 1 (676 aa, $72 \mathrm{kDa}$ ) is encoded by the human LIMD1 gene. This protein plays a role in protein-protein interactions that mediate the repression of gene transcription, cell-cell adhesion, cell differentiation, proliferation and migration. 